\title{
Just plain Wronga?: A multimodal critical analysis of online payday loan discourse
}

\author{
Gavin Brookes* \\ Lancaster University, UK \\ Kevin Harvey \\ The University of Nottingham, UK \\ * Corresponding author
}

\begin{abstract}
Payday loans constitute one of the most rapidly expanding and controversial forms of consumer lending today. Payday lending - the selling of high-interest, short-term credit - has thrived in the wake of the decline of the traditional high street banking system and the reluctance on the part of many mainstream credit services, following the 2007/8 Global Financial Crisis, to lend to low income earners. This study critically examines the website of the industry leader in the UK, Wonga, a payday lender which recently rebranded and relaunched itself (in 2015) after being embroiled in a series of financial scandals. Our analysis centres on the new Wonga website, the gateway to its financial services, and identifies three inter-related discursive strategies through which the lender, in the wake of its financial misconduct, seeks to present itself as a reputable financial service provider, namely by (1) constructing the empowered and responsible borrower, (2) de-stigmatising both its service provision and its prospective customers, the payday borrower, and (3) minimising the consequences and risks associated with payday borrowing. We argue that, collectively, these strategies constitute an artful response by Wonga to the changing legislative and socio-economic contexts in which it and other payday lenders are now required to operate, permitting it to continue marketing and selling its high-interest rate financial services.
\end{abstract}

\section{Keywords}

Payday lending / borrowing, Wonga, multimodality, multimodal critical discourse analysis, online advertising, the fringe economy 


\section{Introduction: the rise of payday lending and the normalisation of high interest credit}

Following the 2007/8 Global Financial Crisis, recent times have witnessed the rise of the so-called fringe economy in which high interest rate financial services, including payday lenders, cheque cashing services and pawnbrokers, seek to profit from the poor and needy (Karger, 2005). The fringe economy has thrived in the wake of the decline of the traditional high street banking system and the reluctance on the part of many mainstream credit services to lend to low income earners. Levels of personal debt have now reached an all-time high, with over 15 million people in the UK, for example, having reported experiencing financial difficulty (StepChange, 2014). In this context of debt and exclusion, coupled with an increase in living costs and a squeeze on real wages (O'Hara, 2015), the UK payday loan market has rapidly expanded, resulting in the 'normalisation' of high interest credit (Hawkes, 2013). It is estimated that across the whole UK consumer credit industry there are 72,000 lenders in operation (Public Accounts Committee, 2013), which, at the expense of the credit poor, have generated huge profits for themselves. In 2004 the UK payday loan industry was worth $£ 4$ million; by 2010 it was worth $£ 1.7$ billion (Packman, 2012) and increasing: during 2013, for instance, 1.6 million people took out 10 million loans to the total value of $£ 2.5$ billion (Financial Conduct Authority (FCA), 2014).

The huge profits accrued by payday lenders are largely due to the high charges associated with their financial services. Although definitions vary (and indeed some payday loan companies, Wonga included, argue that the credit services they offer do not constitute payday lending per se), a payday loan can be defined as an unsecured type of credit that permits an individual to borrow an average of $£ 300$ (from an upper limit of $£ 1,000$ ) over a short period of time (typically a month, or until the borrower's next payday). Payday lending is often described as a 'predatory' type of lending in that it is made available to individuals with poor credit ratings who, in turn, are charged exceptionally high levels of interest, typically a four-figure annual percentage rate (Brown \& Woodruffe-Burton, 2015, p. 109). Payday loans, moreover, can be 'rolled-over', meaning that customers are able to defer the repayment of their loans, although doing so incurs additional (and often very costly) charges. It is this sharp incremental rate of interest, so typical of payday lending, that has resulted in many customers struggling to repay debts which have spiralled out of control. The problem is exacerbated by the fact that many people who take out payday loans do so not on one-off or special occasions, as is often claimed by payday lending companies, but on a routine basis in order to meet the cost of day-to-day living - to purchase essentials such as food and clothes, and to pay household bills (O’Hara, 2015).

The payday loan industry nevertheless continues to buoyantly maintain that it offers a legitimate and useful lending service, and that its exorbitant charges are justified because of the heightened risk of conducting business with a financially unstable population (Karger, 2005, p. 10). Such a risk, however, is in fact more than adequately compensated by the economic phenomenon known as the 'socialisation of loss', which ensures that, regardless of the amount of risk to which they are exposed, payday lenders can still be certain of making substantial financial gains. This is because although some people will default on their loans - indeed a third of all loans are never repaid (Office of Fair Trading (OFT), 2013) - a sufficient number will always meet their payments, thereby guaranteeing high-profit returns for lenders. Indeed, so reassuringly lucrative is the financial cushion that is the sociology of loss that many payday lenders, in their bid to amass as broad a base of customers as possible, have often failed to carry out stringent affordability assessments on potential customers (OFT, 2013). This is a recurring criticism of payday lenders (Packman, 2014a) and one which has led to a succession of customer complaints about them (Govan Law Centre, 2013). 
Although payday lending services have battened, and continue to batten, on the poor and vulnerable, causing many thousands of people untold misery, the financial practices of these predatory lenders have, remarkably, received very little critical scrutiny from discourse analysts, not least in the area of critical discourse studies. This is all the more surprising given that payday lenders have evolved a sophisticated (and extremely insidious) set of discursive techniques through which to promote their services and blandish consumers into taking out loans which they will struggle to repay. To date, most research into payday loans and indebtedness has been undertaken by investigative journalists and sociologists (Packman, 2012, 2014a, 2014b; O'Hara, 2015) and from within the domain of behavioural finance (Bertrand \& Morse, 2011), this latter body of research aiming to account for the decision-making processes that drive consumers' financial transactions. While these studies have revealed much about the intricacies of payday loans and the various motivations behind customer purchasing, they have paid scant semiotic attention to the persuasive and manipulative discourse strategies characteristic of payday loan marketing and the web platforms through which customers obtain financial services. These subtle semiotic techniques, which are not confined to the linguistic level, are, we argue, designed to manipulate discourse and emotions, for example, over-simplifying essential terms and conditions and glossing over or backgrounding the consequences of not being able to pay off debt (Brown \& Woodruffe-Burton, 2015, p. 109). Our analysis focuses on the largest and arguably most well-known payday lender currently operating in the UK, Wonga, critically examining the inter-related textual and visual discursive techniques through which this most prominent of lenders endeavours to construct itself as a reputable and responsible financial service provider.

\section{The rise, fall and relaunch of Wonga (the face of payday lending)}

Since its launch in 2007, Wonga has relentlessly strived to establish itself as a household name in the short-term loan industry, all the while promoting a friendly, informal corporate image in an effort to make light of its principal business: usury - the selling of extortionately high interest loans. This longstanding charm offensive was most forcefully executed via an aggressive and extensive publicity campaign which involved advertising slogans on buses and tubes, the sponsorship of a number of football clubs (including Premier League side Newcastle United), and a protracted series of 'comic' television commercials that featured a nauseously recurring trio of playful puppets (whose characteristic high-spirited behaviour conveyed the warped sense that payday lending was somehow fun, risk-free and inexpensive).

Wonga has an international reach. Besides trading in the UK, it conducts its business in Spain, Canada, Germany, Poland, and South Africa. Since its first appearance on the market, it has made substantial profits, culminating, in 2013 , in a record annual gain of $£ 62.5$ million - an amount that represents loans totalling $£ 1.2$ billion taken out by over one million customers (O'Hara, 2015: 73). Its commercial success was precipitated by two significant innovations in payday lending provision (Packman 2012): (1) the introduction of a virtual sliding scale with which customers are able to swiftly and easily specify the amount of money they wish to borrow and the amount of time for which they want it, and (2) the use of a secret algorithm that very quickly (in around 15 minutes or thereabouts) establishes whether a candidate for a loan is creditworthy or not. Thus the appeal of this virtual interface was - and still is - that customers are able to obtain a loan in a short space of time without having to physically present identification or proof of address, thereby insulating themselves from some of the stigma and stress associated with purchasing payday loans, which is amplified in face-to-face contexts (Sullivan, 2012). 
But despite its initial commercial success, Wonga (and other payday lenders) soon came under the scrutiny of financial regulators. Alongside a number of other improprieties, the company was accused of: failing to properly assess its customers' ability to make repayments, falsely promoting its payday loans as products that could actually enhance customers' credit ratings and, most notoriously of all, sending threatening letters from fake law firms to customers who were struggling to repay loans (Peachey, 2015), this later activity constituting prima facie criminal conduct. The Financial Credit Authority (FCA) found the lender guilty of financial misconduct, ordering it to pay $£ 2.6$ million in compensation to its customers, as well as ordering it to write off $£ 220$ million of client debt (Bachelor \& Neate, 2014). As a consequence of Wonga's transgressions (and misconduct across the payday lending industry more broadly), the FCA, in 2014, imposed a series of regulations on payday lenders, including the requirement for lenders to undertake stricter affordability checks on loan applicants, to cap the cost of loans, and to include prominent risk warnings on all financial promotions (FCA, 2014).

In response to these regulatory measures and a subsequent drop in its annual profits, Wonga underwent, in 2015, a substantial rebranding exercise, radically overhauling its existing website and launching a new promotional campaign. Such endeavours were designed not only to accord with the new FCA regulations but also to promote Wonga as a newly responsible and transparent lender. The company appointed a new CEO and adopted a revised wordmark (which we discuss in our analysis section). Yet for all its efforts to improve its tarnished image, Wonga, so commentators claimed, still continued to target the financially vulnerable, its rebranding exercise being merely an artful attempt to make it appear respectable in the eyes of the borrowing public. As Dave Prentice, the general secretary of the public service Unison, recently put it, Wonga's promotional relaunch has been little more than 'a cynical attempt to lure low-paid workers struggling to make ends meet' (Ellis, 2015). This is not to suggest that the lender has failed to respond to the aforementioned financial regulation, but to argue that, since Wonga's (like other payday lenders') profits depend on having as many customers take up its services as possible, it continues to deploy a persuasive rhetoric designed to encourage the widespread purchase of high interest credit.

\section{A multimodal critical approach to the discourse of payday lending}

This study examines the multimodal discourse in Wonga's new redeveloped website. ${ }^{1}$ The internet has helped to promote the development of the fringe economy and its lending services (Karger, 2005). In terms of accessibility and convenience, the internet constitutes a popular medium for contemporary financial advertising (Cook, 2001) and, because of its wide reach and its cloak of anonymity, affords customers the opportunity of accessing financial services remotely, conveniently sidestepping the potentially awkward predicament of having to secure loans in a potentially intimidating face-to-face setting. The internet, moreover, serves as the principal means through which consumers actually apply for short term credit (Stegman, 2007).

The Wonga website is couched in a heteroglossic, informative-cum-promotional discourse and its homepage doubles up as a 'point of sale', the interface through which users actually apply for loans. Intended users of the website appear to be prospective and returning borrowers, who can log in using a unique username and password. This site contains a total of 95 individual pages, with existing pages modified and new pages added all the time, constituting, all told, an infinitely rich and detailed set of semiotic resources (Kress \& van Leeuwen, 2001). Key domains of the website, accessible through the homepage, include: information about Wonga itself ('About us'), details regarding the borrowing process ('How it works'), and a hub for returning users to view the details of their previous and current borrowing activity ('My account'). Although our analysis explicates discourses 
that permeate the Wonga website in its entirety, our principal focus is on the homepage - the landing point at which every website visitor will arrive, actually apply for a loan and access other key domains of the website. The website was initially retrieved for analysis during March 2015 and examined through until September 2015.

Commercial websites are characteristically multimodal, incorporating into their design language, image, layout, colour, font and so forth, to convey meaning and represent people and things in the world (Martinec \& van Leeuwen, 2009). In order to apprehend as far as possible the Wonga website in its full multimodal array (Machin, 2013), we adopt a multimodal approach to critical discourse analysis (hereafter MCDA) (Machin \& Mayr, 2012: 6-10). We examine the multi-semiotic choices (Hodge \& Kress, 1988; Kress \& van Leeuwen, 2006) made in the design of the Wonga website in order to identify how the social actors and processes involved in payday lending are discursively represented across this text (van Leeuwen, 2008). We then unpack these representations to unearth the ideological and commercial motivations that underlie them (Fairclough, 1995; Fairclough \& Wodak, 1997). Following the recommendation of Kress and van Leeuwen (2001), our analysis explores the semiotic choices evident in the Wonga website in relation to the strata of discourse, design, production and distribution to pursue the following research questions:

Discourse design

- Representations: What social actors and processes are depicted in the website, and how are these linguistically and visually represented?

- Negotiating identities and relations: What types of social relations are constructed (both in language and image) between the represented participants in the website and website users? Further, what attitudes and assumptions about payday borrowing / lending do the language and imagery convey to website users?

Discourse audience and reception

- How are website users / prospective borrowers positioned, what kinds of roles are afforded to them by this website?

Discourse as sociocultural practice

- What insights do the combined use of language and image reveal about the underlying ideologies of the website, particularly relating to payday borrowing / lending?

Adapted from Harvey (2013, p. 696)

In answer to these questions, we identified three recurring discursive strategies operating across the pages of the Wonga website, through which the lender seeks to promote the use of its services. These include: (1) constructing the empowered and responsible borrower, (2) de-stigmatising Wonga and the payday borrower, and (3) minimising the consequences and risks associated with payday borrowing. While we recognise the inclination of these strategies to overlap with and supplement each other throughout this text, for the facility of analysis we provide a separate analytical account of each. 


\section{Wonga: constructing the empowered and responsible borrower}

The new Wonga website goes to significant lengths to depict its existing and prospective borrowers as economically incentivised and responsible individuals who carefully manage their personal finances in the course of their daily lives. The most elaborately multimodal occurrence of this strain of representation can be found in the homepage (see figure 1), arriving at which website visitors are immediately confronted with the naturalistic photographic image of a young, seemingly contented woman (as suggested by her gently smiling countenance) in a clearly identifiable conventional domestic setting. This image contains a number of carefully selected details and 'objects' (Barthes, 1977, pp. 22-23) which help convey the impression that this participant, evidently a Wonga borrower, is a responsible, hard-working and devoted mother. These positive qualities are symbolically reflected in the general cleanliness and orderliness of the kitchen (Berner, 1998) in which the woman is actually working, cleaning a cup, at the moment captured by the photograph. To this, the subtle object of the small tomato plant resting on the worktop - incidentally of the Lycopersicon esculentum variety, otherwise known as the 'Money Maker' (Royal Horticultural Society, 2015) - potentially invokes the sense of this participant's money-saving and financially responsible nature, for she is someone who takes the cost-effective measure of growing fruit which would supplement the family's source of food and so, if only modestly, reduce their outgoings. Although other family members are physically absent, the otherwise harmonious, family-inflected nature of the scene is further suggested by the wedding and engagement rings, clearly visible on the woman's left-hand ring finger, and, more noticeably, the child's colourful pictures, inscribed with the hand-painted label 'MUM', a detail which puts us in little doubt that the woman is a parent.

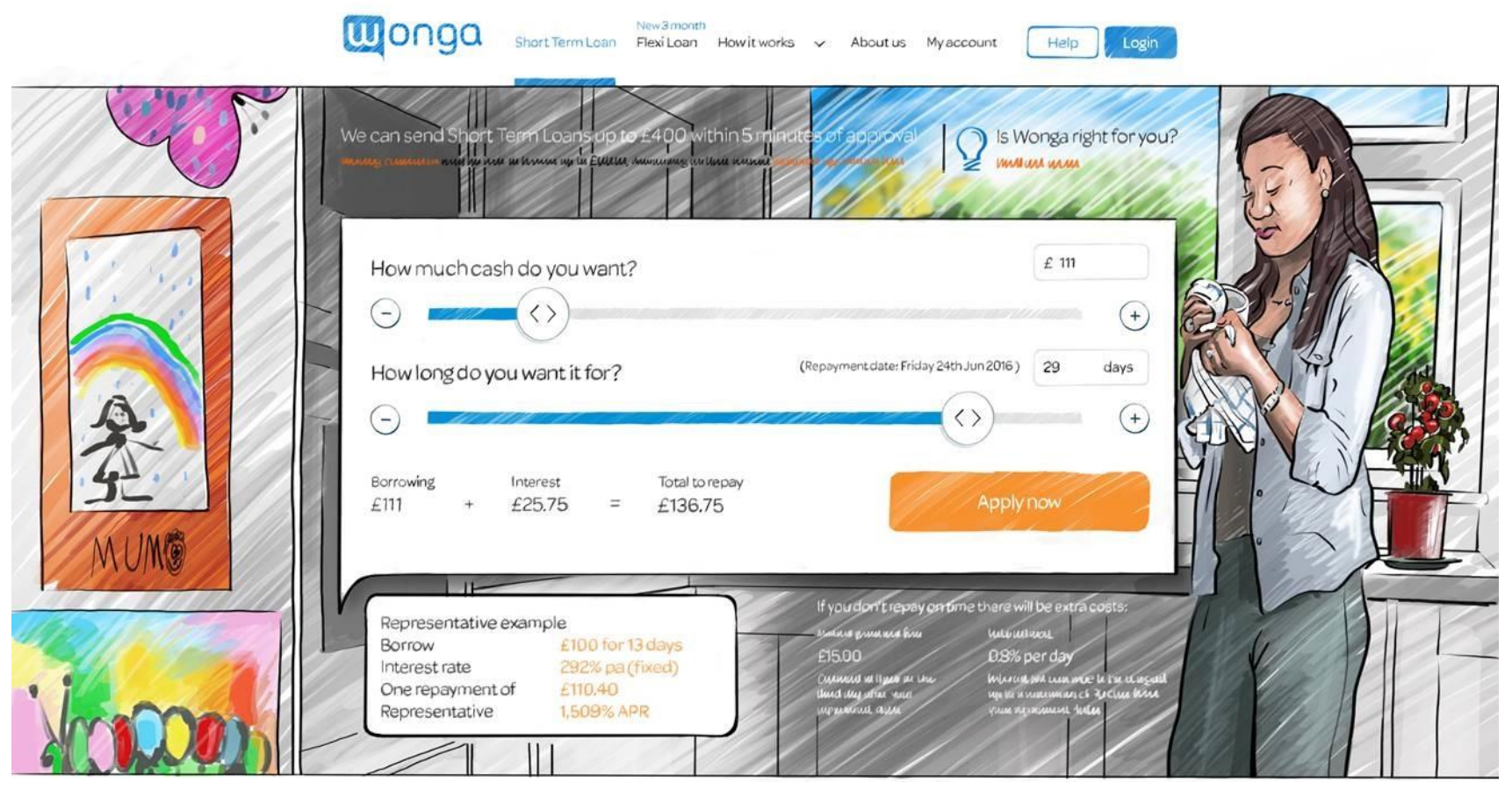

Figure 1: Top-half of the website homepage.

It is perhaps not too much to claim that, as prospective borrowers, we are asked to see this woman's family finances in similar positive terms as the appearance and character of the kitchen (i.e. in terms of the qualities of cleanliness, orderliness and minimalism). In fact, the core advertising themes of 
simplicity, cleanliness and clarity more generally are prevalent not just in this particular image of contentedly well-kept home life, but appear consistently throughout the entire website, connoted most notably through the dominance of a closely-coordinated palate of the cleansing and calming hues of blue, white and grey (Kress \& van Leeuwen, 2006, p. 229), both in the photograph itself (e.g. the participant's clothing, the dish towel, the work surfaces, cupboards and kitchen appliances) and in the graphical and textual elements that surround and are embedded within in it. In addition, the healthy state of this family's finances is further hinted at by the represented participant's gold watch/bracelet and her smart-casual attire, while the well-maintained and vividly in-bloom plants and trees in the garden - colourfully situated directly behind the woman and readily gleaned through the kitchen window - perhaps offer a subtle visual metaphor (Forceville, 2014) for the flourishing growth and relative prosperity that this family presently enjoys.

Not only does this central homepage image convey the impression of a happy, flourishing and secure household, its composition, we suggest, encourages prospective borrowers to align themselves with this idealised setting and scenario. For example, the woman's gaze is directed away from the viewer such that she is "offered" (Kress \& van Leeuwen, 2006, p. 199) to us, presented as an object of contemplation in such a way that symbolically lends the depiction of the domestic scene a degree of authenticity: it is as though we, as viewers, have unobtrusively stumbled upon the woman and her world, while she obliviously carries on with her day-to-day routine (Brookes \& Harvey, 2015). Rather than at an oblique, and thereby marginalising, angle, she appears squarely in front of us, and in a medium camera shot (as opposed to a more distancing long or extreme long shot), which puts us in relatively intimate proximity to her, creating the impression of shared space (Kress, 2010: 59).

Meanwhile, her position on the same vertical plane as us, the viewers (she appears neither above nor below us), contributes further to this sense of parity and convergence (Kress \& van Leeuwen, 2006). In short, not only are we asked, as would-be Wonga customers, to see the woman and her circumstances in potentially enviable and aspirational terms, but we are also asked to perceive the world she inhabits as being within reach of us - just the click of a button away.

Superimposed onto the centre of this image is the pivotal loan application and sliding scales graphic through which prospective customers determine how much money they would like to borrow and for how long. This user-driven element encourages borrowers to freely manipulate the moveable scales in search of the right amount, an interactive and immersing feature (Ensslin, 2012) which affords a degree of agency and control over the lending process. ${ }^{2}$ These sliding scales not only present, but actually render, the process of obtaining a loan as straightforward and requiring relatively little deliberation on the part of the borrower, who is not even required to type in the amount they are borrowing. The ostensible sense of control and financial entitlement afforded by the easy influence over the sliding scales is purposely complemented by various linguistic elements. For instance, the scales are headed by the open questions 'How much cash do you want?' and 'How long do you want it for?', each of which suggests that the terms of the loan agreement will be stipulated entirely by the user's 'want(s)'. Similar potentiating linguistic descriptors are observable elsewhere in the website, for instance in the section titled 'How it works', in which the process of applying for and taking out a payday loan is lexicalised through the alluring and potentially transformative journey metaphor (Smith \& Sparkes, 2004, p. 624) in user-directed expressions such as 'Your journey using Wonga' and 'Getting Started', which euphemistically present the gritty business of usury in terms of possibility and opportunity - a positive undertaking over which customers have ultimate personal control.

Since FCA regulations forbid payday lenders from promoting what might be perceived as irresponsible spending, what Wonga's loans appear to offer to borrowers here is not the immediate financial means to purchase specific (and relatively costly) objects (such as a new car or holiday 
abroad, etc.) but a form of empowerment and security that enables them to 'sensibly' manage their finances and their day-to-day lives more generally, with the hard-working, comfortable and respectable lifestyle depicted on the homepage serving as a kind of example of how this routine project can be realised. In appropriating such potentially empowering and self-determining discourses to promote its services, Wonga appears to target those members of society who, most likely due to their poor socio-economic circumstances, feel financially marginalised and disempowered, particularly those who are under-financed by mainstream lenders (Packman, 2014a) and are struggling financially. However, the framing of Wonga's services as an empowering and responsible means of self-actualisation is, at the very least, problematic. As we pointed out at the beginning of this paper, research suggests that payday loans actually have, if anything, a

disempowering effect on consumers, who not infrequently end up entering a cycle of borrowing and state of perpetual indebtedness to lenders, on whom their long-term financial security becomes dependent (a picture far removed from Wonga's somewhat romanticised scenario) (Stegman \& Faris, 2003). The empowering, self-actualising discourse on which Wonga draws therefore serves not only to (obviously) idealise its lending provision, but also to conceal the sense of disempowerment typically associated with payday loans and the reality of a life dependent on expensive, high-interest credit.

\section{De-stigmatising Wonga and the payday borrower}

Following the toxic press that it received from legislators, consumer watchdogs and sections of the media alike, it is not surprising that Wonga has strived to alleviate the reputation-damaging stigma popularly associated its business practices. As we noted earlier Wonga, in 2015, took part in a substantial rebranding exercise which was designed to enhance its tarnished brand image, promoting itself as responsible and transparent credit service. One of the most significant changes it made was the adoption of a brand new logo - similar to its predecessor but different in a number of curious semiotic respects, all of which can potentially be seen to reflect a departure from a troubled past (figure 2). The lettering of the new logo, for instance, carries less weight but greater curvature (van Leeuwen, 2006: 148-49) than its former incarnation - a typographical detail that conjures notions of relative modesty and, because of the more rounded letters, warmth and friendliness (Machin, 2013: 348). The background blue against which the lettering appears is subtly different too: it is a variegated blue, moving through a dark-medium blue at the bottom of the design gradually through to a lighter, brighter (and hence more optimistic) sky blue at the top, potentially suggesting a positive transformation, a new dawn or beginning. In addition to the font change - the shift away from sharp angularity to a softer roundedness - the letters of the new logo are significantly further apart and surrounded by an increased amount of space, contributing to the impression of a less technical, less harsh-looking design. The new wordmark, moreover, appears dead centre within this generous border. Although potentially conveying the sense of clean, pared down modesty, this surrounding, decontextualised space also suggests a lack of clutter - and in turn the values of simplicity and clarity, which are indicative perhaps of a separation from other things, a symbolic tidying up. 

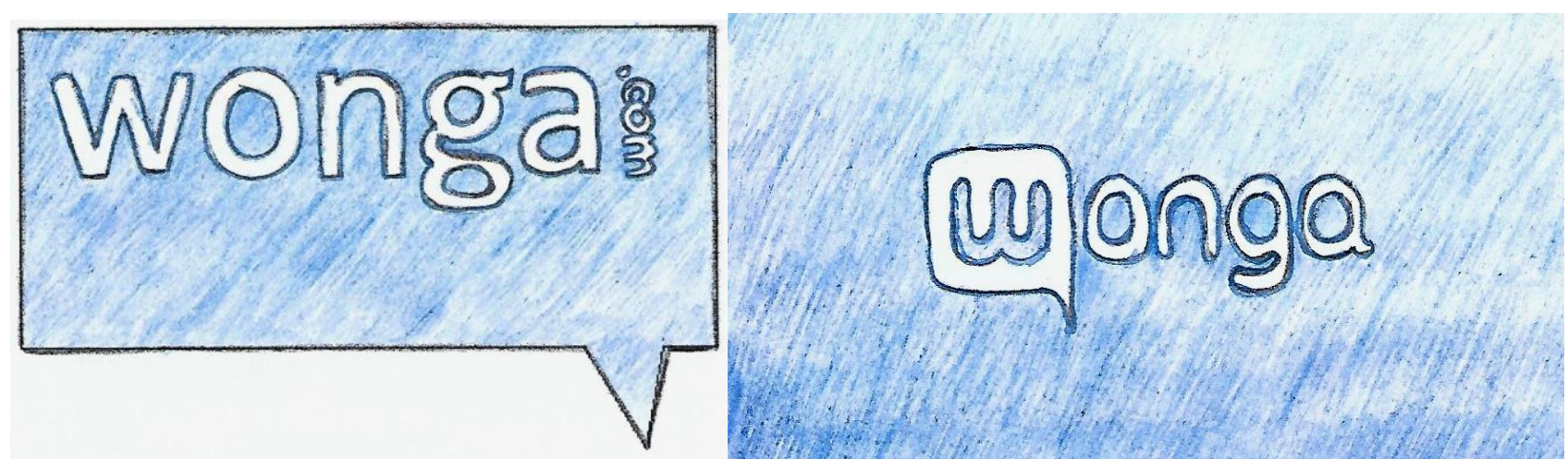

Figure 2: Old (left) and new (right) Wonga logos

If the new Wonga wordmark is a relatively subtle, if signal, semiotic feature of Wonga's rebranding, various lexical choices and syntactical structures which recur throughout the website attest to Wonga's transformation more emphatically. These prominent linguistic elements crystallise, broadly, around notions of corporate responsibility, accountability and altruism. For instance, the page titled 'Our vision', a section of the site which serves as a seeming mission statement for Wonga, sets out various so-called 'values', the linguistic formulation of which are replete with discourses of corporate responsibility, accountability and altruism. For example, Wonga describes itself as 'principled', 'responsible, accountable and transparent', as putting 'people first' and as 'always striv[ing] to do the right thing'. Within this page, the lender also claims to build its business 'around our customers', to 'understand their lives' and to 'do all we can to meet their needs' by 'listening and finding better ways to serve our customers'. However, these commitments and assurances never advance beyond this positively-loaded self-promotional rhetoric to provide any concrete detail about how Wonga is actually changing its lending practices to adhere to the guidance (or demands) of legislators and to meet its own aims.

Our search for such information leads us to the promisingly titled 'Wonga is changing' page, but again a subtle strategy of avoidance and omission of detail characterises much of the lender's commercial rhetoric here. This section of the website features a series of questions, each of which refers to a stigmatised aspect of Wonga's lending practices (irresponsible lending, hidden costs and extortionate financial penalties), along with the lender's seemingly assuring and unequivocal responses. A series of striking visual differences between the speech bubbles containing these opposing "voices" (for example in figure 3, below) helps to discredit the accusations contained in the questions while also categorically representing Wonga in an inviolably positive way. For instance, the choice to frame the questions (and encoded criticisms) in red speech bubble graphics arguably imparts onto the linguistic content a sense of anger and even fear (as well as the sense, perhaps, of being false or incorrect) (Aslam, 2006). On the other hand, the blue speech bubbles onto which Wonga's responses are projected, as well as constituting Wonga's signature brand blue colour, might also connote a sense of calmness and reassurance (van Leeuwen, 2011a) to allay the fearful and emotionally-charged accusations encoded in the accusatory questions. Meanwhile, Wonga's responses are also arguably granted stronger epistemic modality by their being projected in a larger typeface (van Leeuwen, 2006) and onto considerably larger speech bubble graphics, which occupy a significantly larger portion of the on-screen viewing area.

The accusations directed at Wonga are also undercut linguistically in the text within the speech bubbles representing both Wonga's "voice" and the accusatory questions. The questions' 
lacking any attribution arguably presents them as rumour or hearsay, thereby undermining their provenance and credence - their credibility as worthy allegations. Examining these questions closely, we also note a recurring syntactic structure of the pronoun 'you', followed by a verb phrase denoting some irresponsible and stigmatising lending practice, followed up by the tag question 'don't you?', for example, 'You lend to anyone regardless of their situation, don't you?'. The consistent use of this tag question is interesting and serves, we suggest, to attenuate the illocutionary force of the statements (Holmes, 1983), so that they do not read so much like firm accusations, but rather as statements tempered, somewhat, with uncertainty, which affords the payday lender the opportunity to eminently refute them once and for all.

This effect is compounded further by each of Wonga's responses which, in equally rigid and formulaic fashion, consistently begin with a punchy, impactful and quite categorical denial of the proposition in the question - the bold, unmitigated assertion, 'We don't'. The next part of the response then opens with the phrase 'It's a popular perception that...', before the aforementioned impactful and categorical denial is repeated.

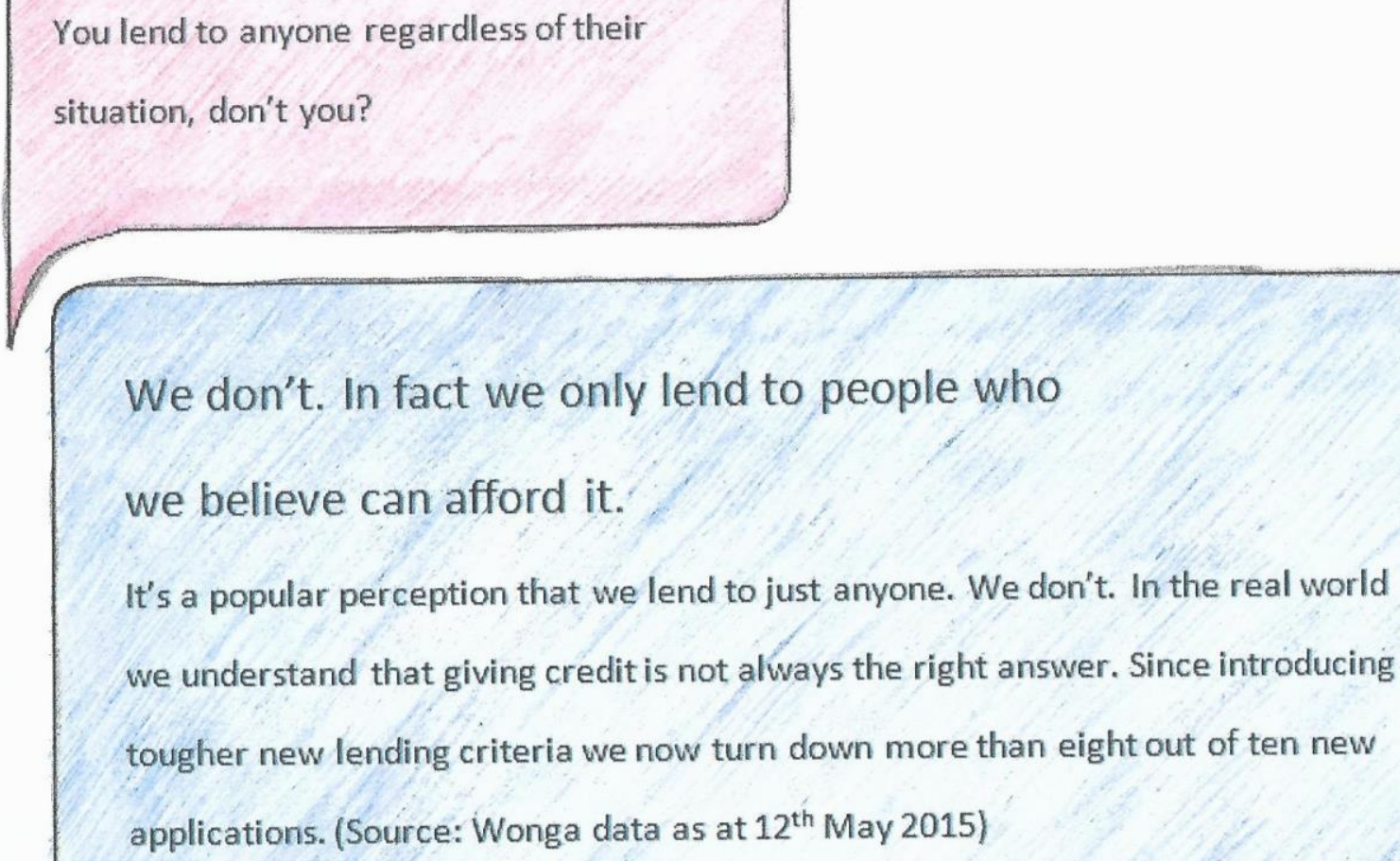

Figure 3: Screenshot from the page titled 'Wonga is changing'.

By describing the propositions of the questions as 'popular perception(s)', Wonga's responses serve to reduce the said accusations to a status of hear-say, while the categorical and hence authoritative-seeming proclamation 'We don't' helps to frame the accusations as misconceptions. Although most likely for legal reasons Wonga could not explicitly label such 
accusations as 'popular misperceptions', the unquestionable and epistemically strong denial that consistently follows it in 'We don't' nonetheless implies that it is a misconception, even if Wonga cannot state that it is so explicitly. It is also worth noting that, although these allegation and denial sequences constitute adjacency pairs, simulating interaction, the questioner never responds to Wonga's denial, suggesting that the lender's response is irrefutable and final. Another phrase featuring in each of Wonga's "replies" is the ambiguous statement 'In the real world we understand that...', which couches Wonga's practices in a consolatory and sympathetic discourse and helps to construe the lender almost as a friend who is understanding of and sympathetic to the problems facing ordinary people - people living in the 'real world' (an extension of the kind of altruistic and person-focussed discourse explored above).

The purportedly responsible, accountable and altruistic nature of Wonga's practices is attested not only in the 'Our values' and 'Wonga is changing' pages considered so far, but is also reinforced through a series of subtle but highly suggestive visual configurations evident throughout the website as a whole. For example, if we return to the website homepage (figure 1) and inspect the subjects of the child's paintings located to the left of the image, it is possible to apprehend a discourse of natural progression that is entextualised through the visual depictions of the evolution of the caterpillar into the butterfly and the emergence of the rainbow following the subsidence of rain. At the heart of this metamorphic imagery is the notion of flourishing and betterment, from one seemingly negative situation to a comparatively positive one. Just as the drabness of the rain is followed by the brightness and beauty of the rainbow, the relatively constrained life of the flightless caterpillar is followed by the relative freedom granted by its transformation into the flying butterfly.

This visual metaphorical sequence seemingly communicates two, we would argue, equally plausible and non-mutually exclusive propositions. On the one hand, we interpret these images as designed to be analogous of the transformative and appealing properties of Wonga loans, which purport to enable borrowers to progress from a bad economic situation to a comparatively better one (an extension of the theme of Wonga as empowering consumers to assume responsibility explored in the previous section). Such a proposition serves to de-stigmatise Wonga by legitimising (van Leeuwen, 2008) its high interest loans on the grounds that they allow borrowers to improve their personal, social and financial standing. A second possible interpretation of these visual metaphors of natural progression is that they connote the purported transformation of Wonga itself, from a once deeply-stigmatised, to now reformed, accountable and more altruistic lender, where the appropriation of the concept of natural progression serves also to naturalise Wonga's previous faults, presenting these as part of the normal - or even natural - maturation process that all businesses go through. However, rather than offer any meaningful, reflective or apologetic admission of previous wrongdoing, including disclosure of the exact details of the offences committed, this discourse serves, chiefly, to normalise Wonga's previous wrongdoing in order to preserve the lender's positive image. The nature of the offences committed, the precise details of which would unquestionably threaten the positive image of itself that Wonga has striven to convey throughout its website, is conveniently omitted altogether.

A central element of Wonga's de-stigmatisation efforts resides in the lender's distancing itself from other, disreputable fringe economy services. Most notable among these strategies is the promotional avoidance, across the entire website, of the term 'payday loan': a loaded expression instinct with negative meaning and toxic social and economic baggage (Peterson, 2008). In fact, Wonga goes out of its way to avoid any lexical association with this freighted term, expressly stating on its homepage that its 'cash loans are an alternative to payday loans as you can choose exactly how much to borrow and for how long', a formulation which might misleadingly imply that its loans are an altogether different kind of financial service, which is evidently not the case, since a short-term high interest loan (i.e. the kind Wonga offer) is, by definition, a payday loan. 
The word 'loan', moreover, occurs relatively infrequently across this website, with Wonga's lending service predominantly linguistically upgraded to the term 'product': a somewhat neutralising expression which relates to a range of goods and hence euphemistically obscures the financial and usury aspect of Wonga's high-interest lending provision. To describe 'loans' as 'products' is to treat them as commodity, a tangible consumer good, downplaying the negative associations (such as debt and indebtedness) that are unavoidably associated with the concept of usury. Moreover, throughout the website, the word 'product' often features in formulations which fetishize the high interest loans that Wonga sells, imparting them with positive and, at times, near-human, animating qualities: 'Our smart financial products', 'Our products are designed to provide solutions', 'Our products help take the headaches out of day-to-day money management'. All told, these types of construction variously construe Wonga's loans as intelligent, ameliorative and bespoke solutions to financial 'headaches'. From a customer's perspective, however, one might reasonably question just how 'pain-relieving' (to adopt Wonga's medical metaphor) is a loan charged at an annual percentage rate of $1,509 \%$ ?

As well as de-stigmatising Wonga's lending practices, the website also deploys a semiotic strategy calculated to concomitantly de-stigmatise its existing and prospective customers, portraying shortterm loans as an unremarkable and non-compromising form of credit service. Returning once more to the website homepage (figure 1), the represented participant, who we are to assume represents a typical Wonga borrower, is, as we noted previously, depicted in a quotidian, everyday domestic setting. We, as website users, would not guess from this image alone that this smiling participant and her family have experienced any financial difficulties in the past. Indeed, this image certainly does not equate with the kinds of stigmatising cultural conceptions of members of the fringe economy as desperate, impoverished and financially irresponsible (Wilson, 2004) which have become prominent in recent years. In fact, as we argued in the previous section, the socio-economic situation attested in this image appears to be quite the opposite, with numerous design-related decisions inviting website users to view this scene as depicting a harmonious and financially-stable familial setting. A potential consequence of the everydayness of this scene is that it construes payday borrowing as an everyday activity, as something that is done routinely by everyone, even those, such as the represented participant in the homepage, who are not evidently experiencing financial difficulties. This discourse of acceptability is also realised through complementary verbal means, with prospective borrowers represented in a manner which emphasises their non-culpability, as well as the seemingly unavoidable nature of their circumstances. For instance, across the website, existing and prospective Wonga borrowers are referred to - somewhat euphemistically - as 'cash constrained', 'under-served' (by the traditional banking system), 'facing real-life financial needs' and as 'being subject to unexpected expenses'. Such ameliorating descriptions arguably seek to de-stigmatise existing and prospective borrowers in as much as they suggest that the need to take out an occasional payday loan is a natural, inevitable part of life and does not necessarily result from any fault or financial mismanagement on the part of the borrower. It is a seductive conceit reassuring customers that, on occasions, many people invariably need a little financial help to see them through, and hence that they are not alone.

And yet in adopting this form of rhetoric, Wonga somewhat undermines its claims to responsible lending. To make significant financial profits, payday lenders, by definition, depend on customers taking out, and defaulting on, more than one loan. Wonga might well convey the surface impression that its lending business is one that conveniently responds to the occasional and unexpected demands of people 'facing real-life financial needs', but what are we to make of the following invitation, couched in small and slender lettering at the top of the homepage, which reads: 'Existing customers may be able to borrow up to $£ 1,000$ '? One would have thought that if Wonga was truly serious about constraining its lending practices, it would, not unreasonably, limit the number of loans per customer 
to no more than one. It is not surprising, therefore, that this invitation for borrowers to take out a larger loan - on condition, of course, that they have already taken out a previous loan - is presented so modestly, both in terms of its font size (van Leeuwen, 2006) and tempering modality ('may be able'), encouraging as it does the kind of cyclical lending that can lead to unmanageable debt. Such an invitation, which is sufficiently mitigated enough so as not to unduly draw attention to itself, nevertheless appears calculated to subtly lure customers into taking out further, and larger, loans - or at least planting this possibility in their minds.

\section{Minimising the consequences and risks associated with payday borrowing}

In accordance with advertising regulations, and following legislation targeted specifically at shortterm credit services (FCA, 2014), Wonga and other payday lenders are now legally required to set out clearly the terms of their loans, including the processes of repayment and certain 'obligatory caveats' (Cook, 2001, pp. 59-60) pertaining to the consequences and penalties incurred by borrowers who miss or stall on repayments. Throughout the Wonga website, we noticed the proclivity for this important information to be mitigated and presented in ways that construe payday borrowing as a relatively low-risk and low-consequence stream of financial credit.

An example of this can be found on the 'How it works' page of the website, within which the process of repayment is described thus: 'We've made repaying simple. We take payment from the debit card you register with us, on the date you request. Just make sure you have enough money in your bank account from 5am on your repayment date.' Here the relatively colloquial tone in which the repayment process is described, for instance as 'simple' and with the adverb 'just' minimising the imposition placed on the borrower, construes indebtedness as a relatively inconsequential matter and one that is always easy to rectify. Likewise, on the same page of the website, the user-directed caveat, 'Short term loans are for occasional use only. You shouldn't use them to manage existing debt, or if you're already under financial strain', although ostensibly fulfilling Wonga's legal requirement to emphasise its commitment to responsible lending by warning prospective borrowers against using payday loans to manage existing debts, adopts a low-modality, weak obligatory tone through the advisory item 'shouldn't' (Fairclough, 1995). This passage would have read quite differently, and conveyed more pressingly the seriousness of this financial commitment, had the word 'shouldn't' been replaced with the directive expression 'must not' or some other formulation of high-affinity modality (Kress \& Hodge, 1988). It is also worth noting that, when discussing payday loans in this potentially negative context, the modifying personal pronoun 'our' is completely omitted in favour of the impersonal and vague 'short term loans'. This nominalising expression generalises this undesirable aspect of Wonga's services, construing them in wider and more abstract terms, as not specific to Wonga loans, or even to payday loans more broadly. Such a passage might also be contrasted with Wonga's ready use of the possessive pronoun 'our' elsewhere on this page (and indeed across the website in its entirety), recurring consistently in formulations which emphasise the helpfulness of the lender's services, for example: 'Our short term loans could help if you have an unexpected expense' and 'Our short term loans could be a big help if you need a small amount of extra cash'.

Similar discourse of risk minimisation can be observed if we return to the questions and answers featured on the 'Wonga's changing' page examined earlier. One pair of speech bubbles relates specifically to the financial penalties that borrowers incur when they delay or miss their loan repayments. Examining the question, which reads 'You sting people with a fee if they miss their repayment date, don't you?', we observe that the financial penalty enforced by Wonga as a result of a missed or delayed repayment is linguistically concealed, denoted by 
the lexical verb 'sting'. On first impression, this strikes as a rather curious piece of loaded vocabulary to appropriate in this context, and one that doesn't appear to do Wonga many favours, construing its late fees as exorbitant or even painful. However, reading on, we notice that Wonga's response in the blue speech bubble, despite going on to actually attest a charge if payments are three days late, actually denies the accusation of 'sting[ing]' its customers, writing:

'We don't. In fact we now give 3 days' grace before applying a missed payment fee. It's a popular perception that we hit people with all sorts of charges. We don't. In the real world we understand that sometimes unforeseen events can make it hard to stick to a plan. That's why we now wait until $11 \mathrm{pm}$ on the third day after the scheduled repayment date before applying a $£ 15$ missed payment fee.'

In denying the accusation (in the twice-recurring two-word expression 'We don't'), Wonga's response skilfully draws a distinction between the kinds of financial penalties that the lender applies and the unfair, exorbitant 'stinging' that is referred in the question, which is (for some reason) equated with the lack of a grace period, rather than the size of the fee: 'We don't. In fact we now give 3 days' grace before applying a missed payment fee.' Note, further, how the financial penalties are described as 'fees' (as opposed to penalties or fines): a euphemistic and comparatively less aggressive expression which arguably invokes notions of a goods exchange or service and downplays its punitive aspect. In addition, Wonga's agency in these fee-related constructions is quite skilfully reserved for the more positive and altruistic propositions. For example, in the expression 'we now wait until $11 \mathrm{pm}$ on the third day after the scheduled repayment date before applying a $£ 15$ missed payment fee', Wonga's agency is foregrounded in relation to the act of waiting, emphasising the lender's patience, but is backgrounded when it comes to the act of actually applying the penalty charge.

In the above passage it is also useful to examine the discursive construction of the payday loan borrower, whose role in the incurrence of a penalty change for a late or missed repayment is concealed - all clauses attesting the application of a penalty charge are grammatically patientless - so as to help reduce any affront to prospective customers who might otherwise be put-off by this negative aspect of this service. Moreover, the act of missing a repayment is itself concealed, never denoted explicitly, but instead formulated as finding it 'hard to stick to a plan': a rather vague form of words which serves to both obscure the financial nature of the agreement and normalise debt repayment (and, in turn, indebtedness), by recontextualising these aspects as a part of everyday life (i.e. the 'real world').

So far in this section we have argued that the consequences and risks associated with Wonga's services are linguistically formulated in a mitigating, low-modality tone. However, this effect is also accomplished visually, with obligatory caveats and terms and conditions typically projected in comparatively small print (van Leeuwen, 2006, p. 148) and inconspicuously relegated either to the bottom of the homepage - tucked away from the guaranteed viewing area or buried deeply in some other page, itself buried away in the website (Cook, 2001, p. 60). For example, turning our attention once again to the homepage displayed in figure 1, we (hardly) notice the warnings relating to the consequences of missed and delayed repayments, which are couched in a low-modality, smaller and more attenuated font (van Leeuwen, 2006), which is barely legible against the cupboard doors that share its feint, white hue, and thus might well be overlooked. 
Note, also, how the information Wonga provides about its high APR (annual percentage rate) is similarly minimal and apparently played down (or at the very least not made as immediately and emphatically explicit as it could of course be). Within the loan application interface, Wonga provides, in an unimposing, sans-serif typeface, the APR figure of 1,509\%. Yet there is no gloss of this initialism or any other nearby explanatory detail that would allow borrowers (particularly those with poor financial literacy) to understand this financial concept and to appreciate the significance of Wonga's (in reality, extremely high) four-figure rate. ${ }^{3}$ Wonga neither expressly gives any indication that $1,509 \%$ is a high rate, nor does it provide any point of comparison - say, the interest rates of other financial services - with which customers could make more informed, and ultimately far less expensive, financial choices. This convenient lack of detail, an act of recontextualisation through deletion (Machin, 2013), is particularly telling respecting customers' ability to make appropriate financial decisions. For the importance of understanding and appreciating the notion of APR is crucial since, as Packman (2012: 61) observes, this particular measure of interest distorts 'the real price attached to a loan that is designed to be short-term, as by definition APR is calculated on a loan duration of a year'. Yet, naturally, it is not in the profit-making interests of payday lenders to draw attention to the unsuitability of APR or to ensure that borrowers fully appreciate the financial implications of its being set at such a (relatively) phenomenally high level.

Wonga also mitigates the risks and consequences associated with payday borrowing by emphasising the professionalism, knowledge and expertise of the individuals working within the organisation. Examples of this self-promoting strategy are abundant across the website but feature most prominently in the page entitled 'The team behind the new Wonga' (screenshot in figure 4, below), which cordially introduces website users to six individuals working within the upper echelons of Wonga's organisational hierarchy.

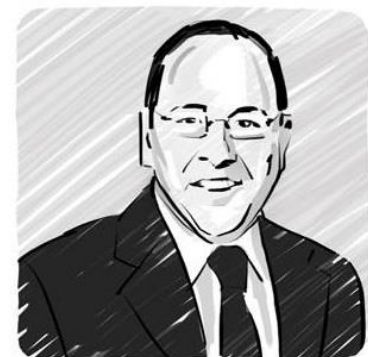

Name

Group Chairman

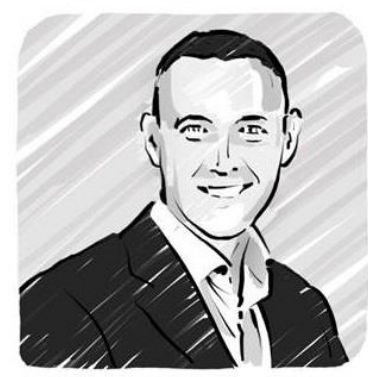

Name

Group Chief Financial Officer (CFO)

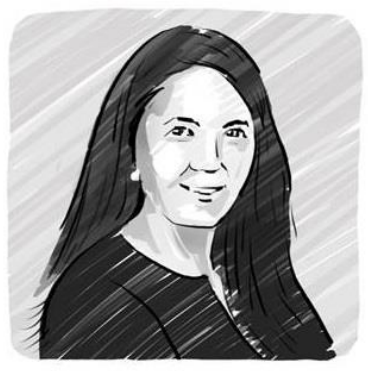

Name

UKCEO

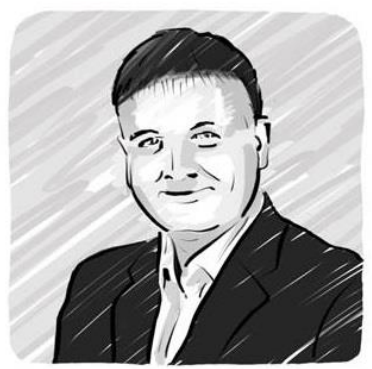

Name

Group Chief Credit Officer

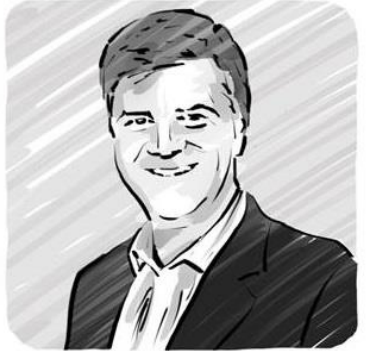

Name

Managing Director, International

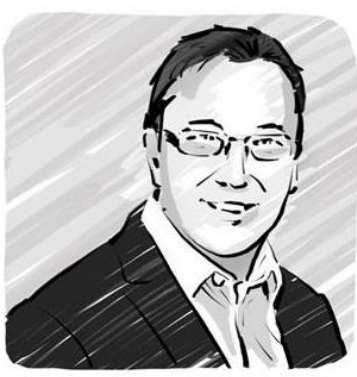

Name

Group Geneıal Counsel

Figure 4: Images of the Wonga leaders taken from the page titled 'The team behind the new Wonga'. 
The page from which this image was taken seeks to attest, verbally and visually, the knowledge and expertise of the Wonga hierarchy. This is accomplished verbally through the choice of lexical descriptors such as 'professionals' and 'specialists' who all have 'strong financial services experience' (where the potent-sounding modifier 'strong' is never qualified). The professionalism and credibility of these participants is also evinced through their visual depictions here, with all of the participants suited in professional attire and pictured in uniform institutional black and white head-and-shoulders photographs, broadly appropriating what van Leeuwen (2008, p. 107) describes as the 'authority of expertise' to convey Wonga's credibility and, in turn, to emphasise the trustworthiness of the services that the lender provides.

As well as presenting itself as led by financial experts, various other semiotic choices also seem to testify Wonga's human-centred approach to lending. For example, Wonga and website users are frequently referred to, respectively, through the familiarising pronouns 'us' and 'you': linguistic choices which synthetically personalise the interaction between these two parties, construing it as a personal, almost private dialogue between familiars (Fairclough, 1989, p. 62). The relationship between Wonga and the website user is also characterised as one of compassion and understanding, such as in the following passage explaining the loan repayment process: 'We always want to help you if you're having financial difficulties and we'll always try to find a solution that works for both of us', which reformulates this legally-binding financial agreement into a kind of therapeutic exchange, wherein debt repayment is reconfigured as a mutually harmonious solution; a burden that is shared by both the borrower and the seemingly empathetic lender.

The personalising effect of Wonga's communication is accomplished not just verbally, but also through a series of carefully-made visual choices, particularly in the screenshot displayed in figure 4 . These participants are all represented as smiling, are pictured in close-up shots which reduce the physical, and hence social, distance between them and website users and their semi-oblique stances and website user-directed eye gazes collectively attest to the willingness of each participant to interact and connect with website users and prospective borrowers. Moreover, that each participant is named and visually represented individually, in photographs with soft, rounded edges (van Leeuwen, 2011b, p. 121), emphasises their personal and approachable natures and renders more personal and private the virtual relationship that each apparently shares with the website users. Collectively, these various choices perform a kind of visual speech act, demanding (Kress \& van Leeuwen, 2006) the attention of, and interaction with, website users on a personal and (seemingly) individual level to emphasise Wonga's purportedly human-centred approach to lending. The prevailing message in this part of the website is, therefore, that Wonga is trustworthy on account of, on the one hand, the professionalism, knowledge and expertise of the people working at the head of its organisational hierarchy and, on the other hand, its personal and human-centred approach to lending.

\section{Concluding remarks}

Despite being, since 2014, a highly regulated industry in the UK, payday lending continues to exercise itself on a grand scale as form of 'pitiless capitalism', making sizeable profits from financially vulnerable people (Hutton, 2014). Our study is, to our knowledge, the first of its kind to critically examine the multi-semiotic strategies operating within payday lending discourse, strategies which are designed to persuade individuals who are potentially denied access to more mainstream credit to take out extremely high-interest rate loans. Although we do not wish to claim that other discursive strategies are not also in operation beyond those we have commented on, we identified 
three clearly apparent, overlapping multimodal strategies through which Wonga strives in this newly regulated market to promote a positive image of itself and induce its website users into harnessing its services, which included: (1) constructing the empowered and responsible borrower, (2) destigmatising Wonga and the payday borrower, and (3) minimising the consequences and risks associated with payday borrowing. All told, these strategies combine to depict Wonga loans as lowrisk, sensible and stigma-free - in other words, an eminently acceptable form of consumer finance or what Wonga, with euphemistic vagueness on its website, calls 'credit for the real world'. Although our analysis has focused exclusively on Wonga, which remains the UK's largest payday lender, we are certain that the kinds of multimodal advertising strategies that we have unpacked here are not exclusive to this lender, but are also utilised by other payday lenders and sections of the fringe economy.

Wonga might well have tempered its former more emphatically persuasive rhetoric, but as our analysis reveals, the lender nonetheless continues to deploy the widespread use of slick and inveigling promotional discourse. It would, therefore, appear to us that despite the increasing regulation of the short-term loan industry, payday lenders are still afforded a fair degree of discursive space in which to market their expensive, quick-decision credit services and, as a result, appear to be adopting a relatively loose approach to the new statutory restrictions. We found recurring evidence of Wonga's subtle and persuasive use of arresting and emotive visual imagery, coupled with its presenting opaque rather than transparent and emphatic warnings - warnings that could easily be more clearly and emphatically communicated in order to highlight, rather than obscure and minimise, the potential dangers and consequences associated with payday borrowing. As Packman observes, if payday lenders were truly responsible creditors and genuinely concerned with helping people in financial difficulties, their websites would direct customers to the services of credit unions rather than seek to seduce them through the subtle interplay of elaborate imagery and Daedalian discourse. But it is, of course, not in the interests of payday lenders to supply customers with unambiguous information about less expensive and more equitable sources of credit, since it is a well-known financial fact that customers who compare their loans against alternative means of finance are less likely to take out larger and successive loans (Bertrand \& Morse, 2011), an outcome sure to compromise lenders' profit margins. Moreover, it seems self-evident that it is not in Wonga's commercial interests to disclose the full and precise workings of its lending process, not to mention of course the true extent its previous financial improprieties. It is not unsurprising, therefore, that such details are obscured, if not (in some cases) elided altogether across its website.

The multimodal critical discourse approach adopted in this paper complements other critical studies of predatory lending. Some of the authors of these studies, as a means of helping people to make more 'rational' decisions about their personal finances, and thereby insulate themselves against the predations of payday lenders, have advocated the increased availability of education programmes to enhance public financial literacy (e.g. Packman, 2012). Given that people with high levels of financial literacy are twice as likely to have lower costs of borrowing (Huston, 2012), this is a sensible and much-needed recommendation. Yet what we hope to have shown in this study is that the commercial discourse of payday lending is carefully designed to rhetorically and emotionally manipulate people into making quick and potentially ill-considered financial decisions. Being steeped in financial literacy might well alert consumers to, say, the budgetary implications of taking out high-interest credit - but it doesn't necessarily account for how subtle promotional discourse might contribute to the making of so-called 'irrational' financial decisions - and hence perhaps will only go so far in protecting consumers from what we might call the 'semiotic blandishment' of rapacious lenders. 
The websites of payday lenders generate meaning through and across numerous levels of semiosis. By harnessing a multimodal approach to discourse, our analysis has sought to explicate some of the potential deeper meanings and effects that might otherwise be overlooked by other approaches to payday lending discourse. The analysis we offer here represents our own critical interpretation of the Wonga website and therefore cannot claim to represent how other reader-viewers will necessarily interact with and understand this rich and multi-layered text. Nevertheless, we suggest that the insights issuing from a multimodal critical discourse approach have something to offer researchers, campaigners and regulators concerned with monitoring the conduct of the payday lending industry in particular insights into how lenders discursively adjust to changes in financial regulation. Profitseekers will always strive to 'push to the limits the rules their societies permit' (Hoggart, 1998: $p$. 60), developing, in the case of payday lenders, ever more guileful techniques to discursively dress up toxic forms of consumer credit, and accordingly we suggest that it behoves critical commentators to be alert to the increasingly insidious processes through fringe economy operators continue to financially exploit the needy and vulnerable.

\section{Notes}

${ }^{1}$ Due to copyright restrictions, the images of the Wonga website reproduced in this article appear as illustrations. Accordingly, we refer readers to the website in its original form, which can be viewed directly at: https://www.wonga.com/.

${ }^{2}$ Arriving at this loan application interface, the sliding scale for the amount borrowed is set at a default value of $£ 111$ - an obscurely random yet memorable figure, and one which carries a number of presuppositions: that this is at least the amount of money that you require (and is already decided by Wonga on the customer's behalf), or at the very least that customers should wish to borrow a three-figure, rather than two-figure, sum. We also contend that the borrower is encouraged, visually and spatially, to drag the sliding scale to the right - and so to increase the amount being borrowed by dint of the fact that there is more space for it to traverse in this direction.

${ }^{3}$ In a study of customers' understanding of the terms and conditions of their payday loans, Martin (2010) found that around 60\% did not know what APR was, and just under 50\% were unable to detail the terms and costs of their loans. The importance of understanding and appreciating the notion of APR cannot be underestimated since, as Packman (2012: 61) observes, this interest measure distorts 'the real price attached to a loan that is designed to be short-term, as by definition APR is calculated on a loan duration of a year'.

\section{References}

Aslam, M., (2006). Are You Selling the Right Colour? A Cross-cultural Review of Colour as a Marketing Cue. Journal of Marketing Communications, 12(1), 15-30.

Bachelor, L., and Neate, R., (2014). Wonga writes off debts for 330,000 customers. The Guardian [online]. URL: < http://www.theguardian.com/money/2014/oct/02/wonga writes-off customer-debt $>$.

Barthes, R., (1977). Image, Music, Text. Hill and Wang: New York.

Berner, B., (1998). The meaning of cleaning: The creation of harmony and hygiene in the home. History and Technology, 14(4), 313-352. 
Bertrand, M., \& Morse, A. (2011). Information disclosure, cognitive biases, and payday borrowing. The Journal of Finance, 66(6), 1865-1893.

Brookes, G., \& Harvey. K. (2015). Peddling a semiotics of fear: a critical examination of scare tactics and commercial strategies in public health promotion. Social Semiotics, 25(1), 57-80.

Brown, J., and Woodruffe-Burton, H., (2015). Exploring emotions and irrationality in attitudes towards consumer indebtedness: Individual perspectives of UK payday loan consumption. Journal of Financial Services Marketing, 20(2), 107-121.

Cook, G., (2001). The Discourse of Advertising (2nd ed.). London: Routledge.

Ellis, M., (2015). Unison slams Wonga TV adverts for 'shamelessly targeting the financially vulnerable'. The Mirror [online]. URL: <http://www.mirror.co.uk/money/city news/unison-slams-wonga-tv-adverts-5768019>.

Ensslin, A., (2012). The Language of Gaming. Basingstoke: Palgrave Macmillan.

Fairclough, N., (1989). Language and Power. New York: Longman.

Fairclough, N., (1995). Critical Discourse Analysis. Boston: Addison Wesley.

Fairclough, N., \& Wodak, R., (1997). 'Critical discourse analysis', in: T. van Dijk (ed.), Discourse as Social Interaction. London: Sage, pp. 253-268.

Financial Conduct Authority (2014). FCA proposes price cap for payday lenders. FCA [Online]: < http://www.fca.org.uk/news/fca-proposes-price-cap-for-payday-lenders>.

Forceville, C. J., (2014). The Strategic Use of the Visual Mode in Advertising Metaphors. In E. Djonov, \& S. Zhao (Eds.), Critical Multimodal Studies of Popular Discourse (pp. 55-70). London: Routledge.

Govan Law Centre (2013). Govanhill success for GLC's Payday Loan Survival Guide as relaunched with Glasgow University's Student Representative Council. Govan Law Centre [online]. URL: < http://govanlc.blogspot.co.uk/2013/12/govanhill-success-for-glcs-payday-loan.html>.

Harvey, K., (2013). Medicalisation, pharmaceutical promotion and the Internet: a critical multimodal discourse analysis of hair loss websites. Social Semiotics, 23(5), 691-714.

Hawkes, S., (2013). Children are watching 70 payday loan ads a year on TV, new report reveals. The Telegraph [online]. URL: <http://www.telegraph.co.uk/finance/personalfinance/10508083/ Children-are-watching-70-payday-loan-ads-a-year-on-TV-new-report-reveals.html>.

Hodge, B., \& Kress, G. (1988). Social Semiotics. Cambridge: Polity Press.

Hoggart, R. (1998). Critical literacy and critical reading. In B. Cox (Ed.), Literacy is not Enough: Essays on the importance of reading (pp. 56-57). Manchester: Manchester University Press.

Holmes, J., (1983). The functions of tag questions. English Language Research Journal, 3, 40-65.

Huston, S. J. (2012). Financial literacy and the cost of borrowing. International Journal of consumer studies, 36(5), 566-572.

Hutton, W. (2014). Shaming Wonga is great, but it won't help people pay the bills. Observer $05 / 10 / 14$.

Karger, H., (2005). Shortchanged: Life \& debt in the fringe economy. San Francisco: Berrett Koehler.

Kress, G., (2010). Multimodality: A social semiotic approach to contemporary communication. London: Routledge.

Kress, G., \& van Leeuwen, T. J., (2001). Multimodal Discourse: The Modes and Media of Contemporary Communication. London: Arnold.

Kress, G., \& van Leeuwen, T. J., (2006). Reading Images: The Grammar of Visual Design (2nd ed.). London: Routledge.

Machin, D., (2013). What is multimodal critical discourse studies? Critical Discourse Studies, 10(4), 347-355.

Machin, D., \& Mayr, A., (2012). How to Do Critical Discourse Analysis: A Multimodal Introduction. London: Sage. 
Martin, N., (2010). 1000\% Interest-Good While Supplies Last: A Study of Payday Loan Practices and Solutions. Arizona Law Review, 52(3), 563- 622.

Martinec, R., \& van Leeuwen, T. J., (2009). The Language of New Media Design: Theory and Practice. London: Routledge.

O'Hara, M., (2015). Austerity bites: A Journey to the Sharp End of Cuts in the UK. Bristol: Policy Press.

Office of Fair Trading (OFT), (2013). Payday Lending: Compliance Review Final Report [online]. URL: <http://webarchive.nationalarchives.gov.uk/20140402142426/http:/oft.gov.uk/shared_ ft/Credit/oft1481.pdf>.

Packman, C., (2012). Loan Sharks: The Rise and Rise of Payday Lending. United Kingdom: Searching Finance Ltd.

Packman, C., (2014a). Loan Sharks: The Rise and Rise of Payday Lending (Revised edition). United Kingdom: Searching Finance Ltd.

Packman, C., (2014b). Payday Lending: Global Growth of the High-Cost Credit Market. Basingstoke: Palgrave Pivot.

Peachey, K., (2015). Will Wonga and other payday lenders survive? BBC [online]. URL: < http://www.bbc.co.uk/news/business-32394286>.

Peterson, C. L., (2008). Usury Law, Payday Loans, and Statutory Sleight of Hand: Salience Distortion in American Credit Pricing Limits. Minnesota Law Review, 92(4), 1110 1164.

Public Accounts Committee (2013). Public Accounts Committee - Eighth Report Regulating Consumer Credit. Available at: < http://www.publications.parliament.uk/pa/cm 201314/cmselect/cmpubacc/165/16502.htm>.

Royal Horticultural Society (2015). Solanum lycopersicum 'Money Maker' [online]. URL: <https://www.rhs.org.uk/Plants/304421/i-Solanum-lycopersicum-i-Money-Maker/Details>.

Smith, B., \& Sparkes, A., (2004). Men, sport, and spinal cord injury: An analysis of metaphors and narrative types. Disability \& Society, 19(6), 613-626.

Stegman, M. A., (2007). Payday Lending. The Journal of Economic Perspectives, 21(1), 169-190.

Stegman, M. A., \& Faris, R., (2003). Payday Lending: A Business Model that Encourages Chronic Borrowing. Economic Development Quarterly, 17(1), 8-32.

StepChange (2014). Debt Awareness Week launches with new survey findings. StepChange Debt Charity. URL: <http://www.stepchange.org/Mediacentre/Pressreleases/DebtAwarenessWeeklaunch. aspx>.

Sullivan, T. A., (2012). Debt and the Simulation of Social Class. In R.Brubaker \& R. Lawless (Eds.). A Debtor World: Interdisciplinary Perspectives on Debt (pp. 36-60) New York, USA: Oxford University Press.

van Leeuwen, T. J., (2006). Towards a Semiotics of Typography. Information Design Journal + Document Design, 4(2), 139-155.

van Leeuwen, T. J., (2008). Discourse and practice: New tools for critical discourse analysis. Oxford: Oxford University Press.

van Leeuwen, T. J., (2011a). The Language of Colour: An Introduction. London: Routledge.

van Leeuwen, T. J., (2011b). The Semiotics of Decoration. In K. O'Halloran, \& B. Smith (Eds.), Multimodal Studies: Exploring Issues and Domains (pp. 115-130). London: Routledge.

Wilson, D., (2004). Payday Lending: Policy Making for the Financial Fringe. Just Policy: A Journal of Australian Social Policy, 33, 17-25.

\section{Author bios}


Gavin Brookes is Senior Research Associate in the ESRC Centre for Corpus Approaches to Social Science (CASS) in the Department of Linguistics and English Language, Lancaster University, UK. His research interests include discourse analysis, corpus linguistics and multimodality.

Kevin Harvey is a lecturer in the School of English, University of Nottingham, UK. His research interests are in the area of discourse-based health communication, which includes corpus linguistic and critical multimodal approaches to health-related discourse. 